\title{
Perancangan Prototype Sistem Pembelajaran Matematika Dasar Berbasis Konsep Guru dengan Peta Pikir
}

\author{
Luh Putu Ida Harinia ${ }^{\text {, I Gede Santi Astawa }}{ }^{b}$ \\ aprogram Studi Matematika, FMIPA, Universitas Udayana \\ bProgram Studi Teknik Informatika, FMIPA, Universitas Udayana \\ Badung, Indonesia \\ aballidah@unud.ac.id \\ bsanti.astawa@unud.ac.id
}

\begin{abstract}
Konsep dasar matematika merupakan materi matematika yang sangat penting dikuasai oleh siswa. Salah satu upaya peningkatan pemahaman siswa adalah terciptanya sebuah sistem pembelajaran berbasis komputer yang mampu memberikan materi sesuai pemahaman siswa. Penelitian penggunaan peta pikir dalam pengembangan konsep pembelajaran matematika oleh guru dalam meningkatkan pemahaman siswa menjadikan latar belakang penelitian mengenai pemanfaatan peta pikir sebagai acuan pembuatan sistem pembelajaran berbasis komputer ini. Dari hasil penelitian pendahuluan yang sudah dilakukan, dapat disimpulkan bahwa penggunaan konsep peta pikir sebagai metode dalam membantu pembelajaran siswa sudah berjalan dengan baik sesuai dengan kebutuhan pengguna. Dan dari hasil pengujian skal kecil oleh 10 orang guru, didapatkan hasil $75 \%$ responden menilai prototype "Sangat Baik" dan 25\% menilai "Baik"
\end{abstract}

Keywords: peta pikir, pembelajaran, sistem berbasis komputer

\section{Abstract}

The basic concept of mathematics is a mathematical material that is very important to be mastered by students. One of the efforts to increase student understanding is a computer-based learning system that is able to provide material according to student understanding. Many research on the use of mind maps in developing the concept of learning mathematics by teachers in increasing student understanding, its become the background for this research. On this research we use mind maps as a reference for making this computer-based learning system. From the results of the preliminary research that has been done, it can be concluded that the use of the concept of mind maps as a method of helping student learning has gone well according to user needs. And from the results of small scale testing by 10 teachers, the results obtained $75 \%$ of respondents rated the prototype "Very Good" and $25 \%$ rated "Good"

Keywords: mind map, learning, computer-based systems

\section{Pendahuluan}

Konsep dasar matematika (matematika dasar) merupakan materi matematika yang sangat penting dikuasai oleh siswa. Berbagai upaya dalam meningkatan kemampuan para siswa pada materi matematika dasar sudah pernah dilakukan seperti yang dilakukan Agata (2015) dengan menerapkan teknik inkuiri terbimbing, atau oleh Triwahyu (2018) dengan menggunakan pendekatan konstruktif. Namun dalam studi pustaka yang dilakukan oleh peneliti, penelitian mengenai peningkatan pemahaman siswa lebih banyak menggunakan metode penanaman konsep atau sering dikenal dengan metode peta pikir. Metode peta pikir mentransformasi alur berpikir seorang guru sehingga dapat lebih mudah dipahami oleh siswa, atau sebaliknya dengan metode ini seorang guru dapat mengidentifikasi faktor-faktor yang menyebabkan kegagalan siswa dalam memahami materi. Sebuah penelitian penggunaan peta pikir dalam pembelajaran matematika yaitu yang dilakukan oleh Muslima Harneli Harneli (2019) dimana dapat dibuktikan bahwa penggunaan metode peta pikir mampu memberikan peningkatan pemahaman bagi para siswa. 


\section{Metode Penelitian}

Pada penelitian ini, peneliti menggunakan peta pikir seorang guru sebagai dasar dalam penentuan arah belajar seorang siswa di dalam sistem pembelajaran berbasis komputer. Penelitian ini didasari oleh sifat peta pikir yang menyediakan grafik keterhubungan antar materi dan juga dengan materi prasyarat jika ada. Dengan penggunaan konsep peta pikir maka sistem pembelajaran berbasis komputer yang dirancang diharapkan memiliki sifat yang adaptif dan mampu mengarahkan pembelajaran sesuai dengan kemampuan yang dimiliki oleh setiap siswa.

Penelitian pendahuluan yang dilakukan sebagai dasar pengembangan sistem diawali dengan melakukan kajian pustaka dan dilanjutkan dengan metode wawancara langsung kepada guru sebagai sumber data peta pikir. Dalam penelitian ini diambil sebanyak 50 contoh peta pikir yang didapatkan dari berbagai macam sumber termasuk dari para guru pengajar matematika dasar. Penelitian dilakukan dengan diskusi pendampingan oleh guru dalam melakukan analisis perubahan peta pikir menjadi konsep database materi termasuk diskusi tentang aturan kelulusan siswa pada setiap materi. Jadi dari hasil penelitian didapatkan konsep database secara umum terhadap berbagai jenis peta pikir, serta aturan-aturan yang dimiliki seorang guru dalam pembelajaran.

Dari hasil analisa dan diskusi serta kajian pustaka yang dilakukan kemudian disusun sebuah model sistem berbasis komputer yang dapat mengambil data peta pikir dan aturan pembelajaran guru. Model ini diimplementasikan menggunakan bahasa pemrograman berbasis web sehingga menjadi prototipe sistem yang selanjutnya dapat diuji oleh para guru. Pengujian oleh guru ini bertujuan untuk mendapatkan kesan dan masukan-masukan terkait model. Selanjutnya hasil analisis dan pengujian yang dilakukan terhadap model database yang dihasilkan, akan diimplementasikan kedalam sistem pembelajaran yang dikombinasi dengan sistem berbasis pengetahuan dengan metode penalaran forward chaining.

\section{Hasil dan Pembahasan}

\section{A. Peta pikir}

Dalam pembahasan ini akan diambil satu contoh analisa sebuah peta pikir dihubungkan dengan konsep database.

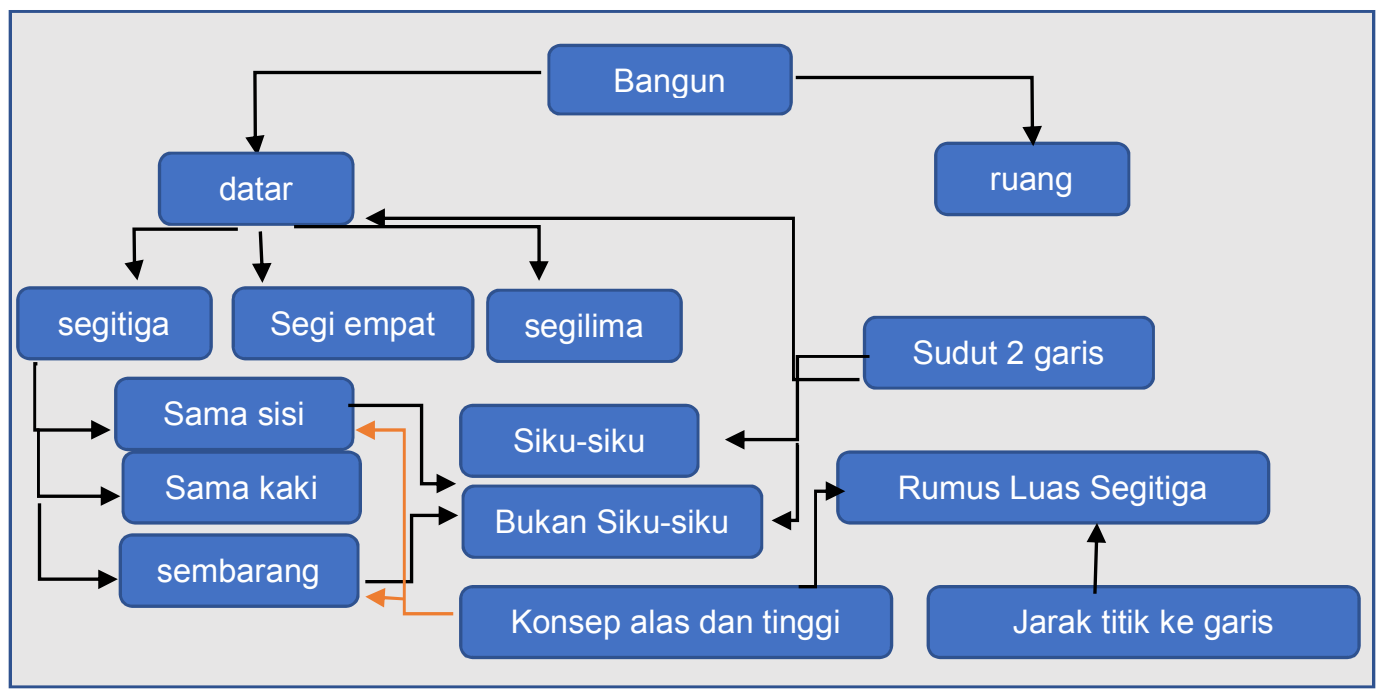

Gambar 1. Peta pikir menghitung luas segitiga

Dari peta pikir pada Gambar 1. Ada beberapa komponen yang didapatkan menjadi karakteristik sebuah peta pikir, diantaranya:

1. Ada materi yang memiliki nilai khas masing-masing, misalkan materi segitiga, maka dia memiliki kekhasan yaitu memiliki 3 buah sudut. Atau materi mengenai bangun datar yang memiliki kekhasan yaitu berupa bangun dua dimensi. Setiap materi dalam peta pikir ini selanjutnya digunakan sebagai sebuah entitas dalam database.

2. Terdapat hubungan-hubungan antar materi :

a. Hubungan "terdiri dari" seperti macam-macam bangun datar yang terdiri dari bangun segitiga, bangun segiempat, bangun segilima, dan lain-lain. Dalam konsep database 
hubungan ini dikonversi menjadi hubungan one to many dimana sebuah entitas dapat terdiri dari beberapa entitas anak, sedang sebuah entitas anak hanya memiliki sebuah entitas ayah.

b. Hubungan "prasyarat dari" seperti pemahaman akan sebuah segitiga siku-siku atau bukan maka sangat penting pengetahuan tentang sudut sudah dipahami terlebih dahulu. Dalam skema database nantinya hubungan prasyarat akan dikonversikan ke dalam skema many to many dimana sebuah materi dapat memiliki banyak prasyarat, dan sebuah prasyarat dapat menjadi prayarat untuk beberapa materi.

c. Hubungan "penjelasan dari" merupakan hubungan antara entitas sebuah materi dengan entitas-entitas yang sifatnya memberi penjelasan terhadap materi tersebut, atau materimateri pendukung lainnya seperti rumus, soal, gambar, teks dan lainnya. Dalam konsep database hal ini dikonversi menjadi atribut dalam sebuah table materi.

3. Terdapat beberapa kategori materi, seperti materi inti, materi prasyarat, materi penjelasan, dan materi aturan.

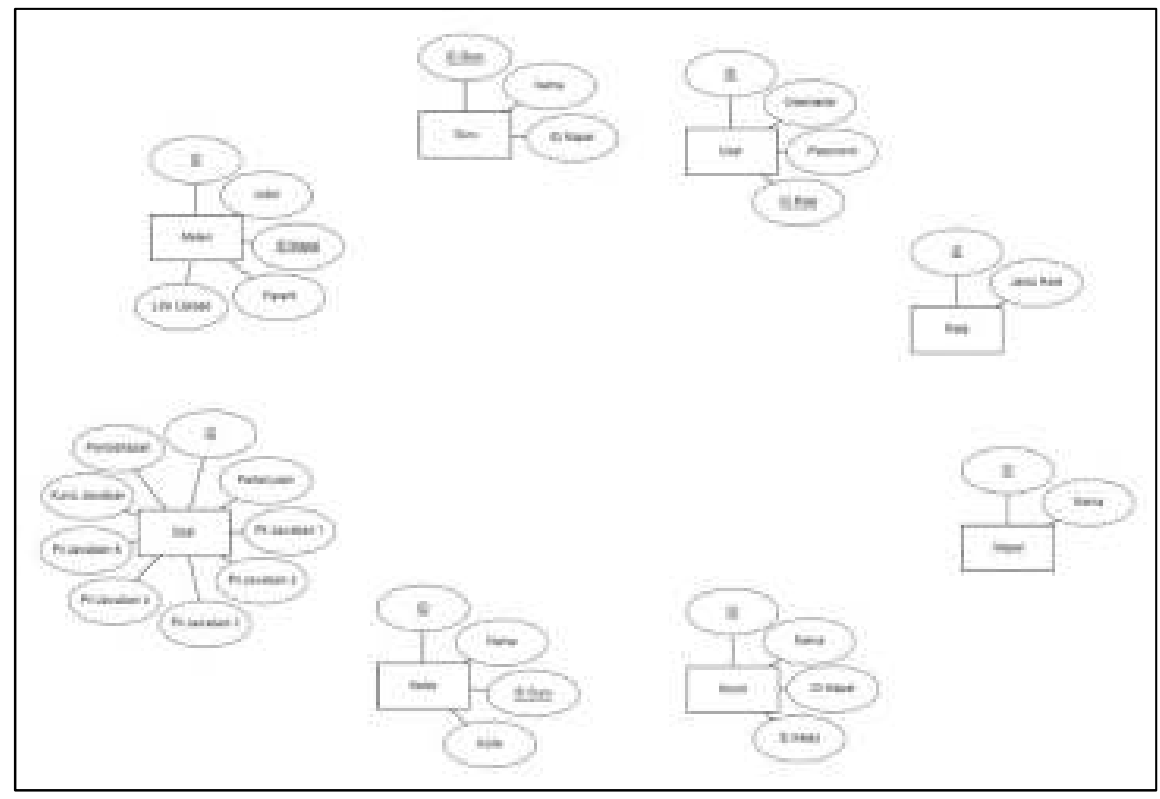

Gambar 2. Rancangan Diagram Relasional dari Prototype System

\section{B. Aturan Pembelajaran Guru}

Dari wawancara dengan beberapa orang guru yang menjadi narasumber penelitian, dapat disimpulkan bahwa setiap guru memiliki standar dan cara penilaian yang sama akan kelulusan seorang siswa, namun terkadang beberapa guru memiliki perbedaan penekanan dalam beberapa komponen penilaian. Terdapat 4 hal dasar dalam penilaian matematika dasar, yaitu

1. Sikap, yang dimaksud disini adalah penilaian sikap siswa akan lingkungan, pembelajaran, dan pengembangan diri mereka.

2. Pemahaman, dalam hal ini seorang guru mengukur tingkat pemahaman siswa terhadap materi

3. Keterampilan, disini guru menilai beberapa hal seperti kemampuan berhitung siswa, kemampuan membaca dan menulis, juga memberikan penjelasan.

4. Kecerdasan, dalam hal ini guru akan menilai tingkat kecerdasan yang dimiliki siswa dengan memberikan soal-soal yang tidak biasa dan membutuhkan penalaran lebih dalam.

Dari keempat komponen tersebut, seringkali komponen ke dua dan ketiga lebih banyak digunakan sebagai dasar kelulusan dengan menggunakan alat ukur hasil ujian siswa. Walaupun beberapa guru juga memberikan penilaian akan kecerdasan dan sikap siswa yang diukur dengan tingkat aktifitas siswa selama proses pembelajaran.

Dari penjelasan tersebut, maka dapat dibuatkan sebuah skema basis data aturan kelulusan dalam bentuk pencatatan komponen penilaian yang dilengkapi dengan skor bobot dari komponen tersebut. Selanjutnya komponen-komponen penilaian ini digunakan sebagai salah satu atribut 
dalam materi, soal, ataupun pencatatan aktifitas siswa. Dari hasil analisa peta pikir yang telah diperoleh, kemudian dirancang sebuah skema database seperti pada Gambar 2.

\section{Perancangan Prototype System Berbasis Web}

Pada perancangan prototype ini sifokuskan pada pelayanan terhadap user guru dalam mengupload bahan-bahan pembelajaran sesuai peta pikir yang dimiliki

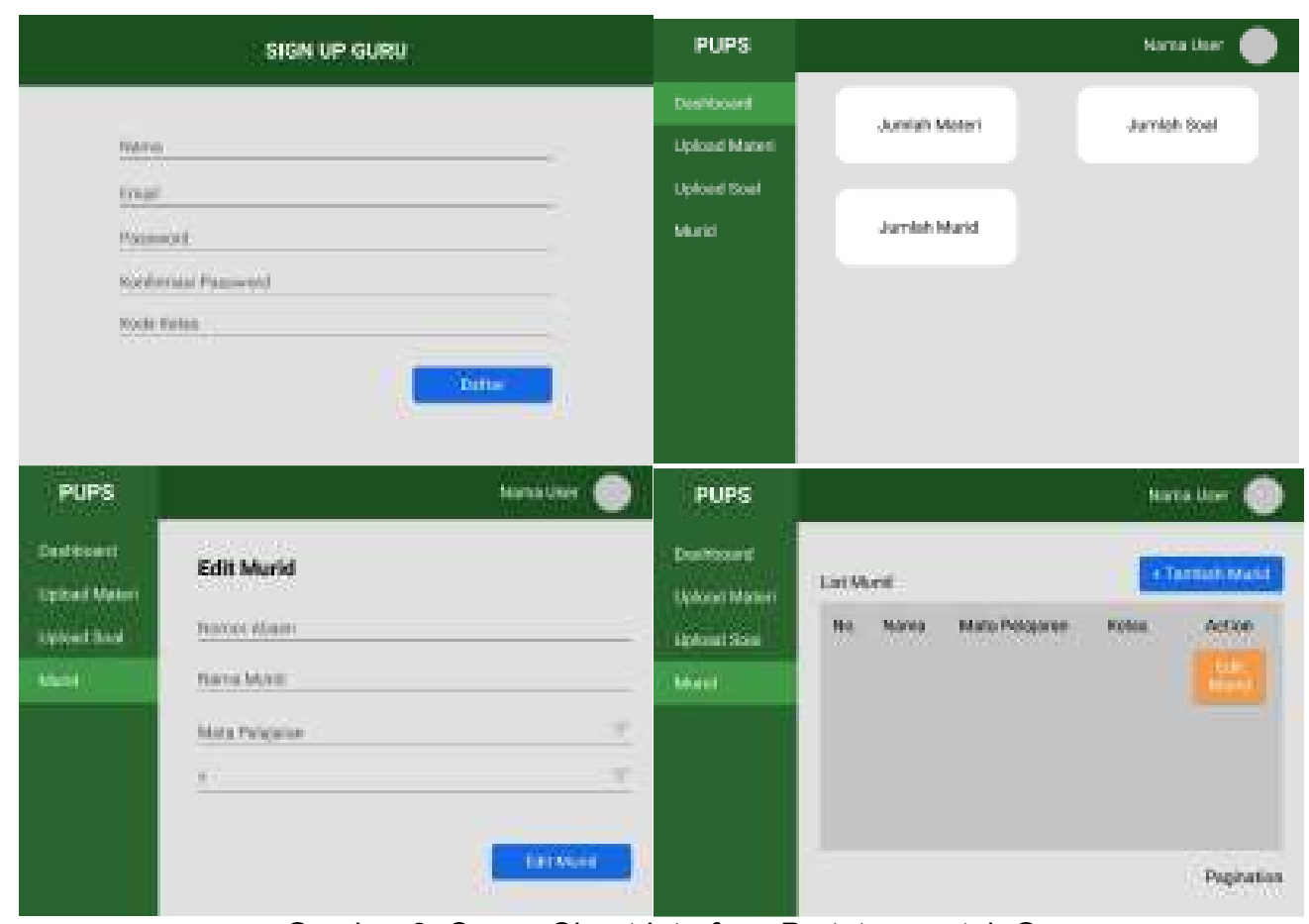

Gambar 3. ScreenShoot Interface Prototype untuk Guru

\section{Pengujian Blackbox terhadap Prototype System}

Pengujian blackbox bertujuan untuk mendapat respon aplikasi terhadap kebutuhan pengguna yang sudah didefinisikan

Tabel 1. Hasil pengujian blackbox

\begin{tabular}{|c|c|c|c|}
\hline No & Fungsi & Hasil yang diharapkan & Hasil Uji \\
\hline 1 & $\begin{array}{l}\text { Dapat melakukan } \\
\text { CRUD terkait materi } \\
\text { oleh pengguna guru }\end{array}$ & $\begin{array}{l}\text { Fungsi CRUD materi berupa } \\
\text { text dapat berjalan dengan } \\
\text { baik }\end{array}$ & Berhasil \\
\hline 2 & $\begin{array}{l}\text { Dapat mengunggah } \\
\text { materi berupa link } \\
\text { video atau website } \\
\text { terkait materi }\end{array}$ & $\begin{array}{l}\text { Prototype dapat mencatat dan } \\
\text { menjalankan apabila guru } \\
\text { memasukkan link ke dalam } \\
\text { materi. }\end{array}$ & Berhasil \\
\hline 3 & $\begin{array}{l}\text { Guru mendapatkan } \\
\text { hasil pembelajaran } \\
\text { siswa secara individu } \\
\text { maupun kelompok }\end{array}$ & $\begin{array}{l}\text { Dapat menampilkan } \\
\text { akumulasi penilaian dari setiap } \\
\text { siswa maupun secara kelas }\end{array}$ & Berhasil \\
\hline 4 & $\begin{array}{l}\text { Siswa dapat } \\
\text { mengakses materi dan } \\
\text { melakukan interaksi } \\
\text { terkait beberapa soal } \\
\text { latihan }\end{array}$ & $\begin{array}{l}\text { Siswa dapat melakukan } \\
\text { proses belajar yang terdiri dari } \\
\text { tahap mengakses materi, } \\
\text { menjawab soal latihan, chat } \\
\text { bertanya, forum kelas, ujian }\end{array}$ & Berhasil \\
\hline
\end{tabular}


Dari hasil pengujian blackbox pada tabel 1, dapat ditarik kesimpulan bahwa prototype yang dirancang sudah dapat memenuhi kebutuhan pengguna.

\section{E. Pengujian Tingkat Kepuasan User Skala Kecil}

Selanjutnya dilakukan pengujian pengguna skala kecil dengan melibatkan 10 orang guru matematika.

Tabel. 2 Hasil Uji Coba Prototype

\begin{tabular}{|c|c|c|c|c|c|}
\hline arameter & Pernyataan & SB & B & CB & TB \\
\hline $\begin{array}{l}\text { Aspek Sistem } \\
\text { Aplikasi }\end{array}$ & $\begin{array}{l}\text { 1. App Mudah dan cepat } \\
\text { digunakan } \\
\text { 2. Alur Appi Mudah } \\
\text { dipahami } \\
\text { 3. Fitur App dapat } \\
\text { ditelusuri dengan baik } \\
\text { 4. Fitur pencarian App } \\
\text { dapat digunakan } \\
\text { 5. Tombol-tombol pada } \\
\text { app berfungsi }\end{array}$ & 8 & 2 & 0 & 0 \\
\hline $\begin{array}{l}\text { Aspek Konten } \\
\text { Aplikasi }\end{array}$ & $\begin{array}{l}\text { 1. Tulisan Teks App } \\
\text { terbaca dengan baik } \\
\text { 2. Bahasa teks pada } \\
\text { App dimengerti } \\
\text { 3. Informasi pada App } \\
\text { mudah dipahami } \\
\text { 4. Informasi pada App } \\
\text { menarik perhatian } \\
\text { 5. Informasi pada App } \\
\text { sesuai dengan tema } \\
\text { materi }\end{array}$ & 7 & 3 & 0 & 0 \\
\hline Skor & & $\begin{array}{c}15 \\
(75 \%)\end{array}$ & $5(25 \%)$ & 0 & 0 \\
\hline
\end{tabular}

Keterangan: SB = Sangat Baik, B = Baik, CB = Cukup Baik, TB =Tidak Baik

Dari hasil pada table 2. Dapat ditarik kesimpulan bahwa prototype yang dibangun sudah sangat baik karena diatas $75 \%$ sudah menyatakan aplikasi "Sangat Baik" sedang $25 \%$ lainnya menyatakan "Baik".

\section{Kesimpulan}

Dari hasil pengujian blackbox dan pengujian respon pengguna skala kecil yang sudah dilakukan, dapat disimpulkan bahwa

1. Prototype yang dirancang sudah memenuhi empat kebutuhan pengguna yang telah didefinisikan.

2. Sebanyak $75 \%$ pengguna menyatakan sistem sudah sangat baik dan $25 \%$ lainnya menyatakan bahwa sistem sudah baik.

\section{Ucapan Terimakasih}

Tulisan ini adalah hasil penelitian pendahuluan dari hasil Penelitian Unggulan Program Studi pendanaan tahun 2020. Atas dipublikasikannya penelitian ini, maka pada kesempatan ini kami mengucapkan terima kasih kepada Universitas Udayana atas bantuan dana yang dibiayai oleh DIPA BLU Universitas Udayana Tahun Aggaran 2020. 


\section{REFERENSI}

Agata Sri S, Dwi Uswatun H., 2015., Upaya Meningkatkan Pemahaman Konsep Matematika Dengan Model Pembelajaran Inkuiri Terbimbing Siswa Kelas VIII C SMP Negeri 11 Yogyakarta., Jurnal Derivat, Volume 2, Nomor 2, Halaman 56-54.

Muslima Harneli Harneli, Irwan Koto Koto, Endang Widi Winarni, (2019), Penerapan Learning Cycle 5e Melalui Peta Pikir Meningkatkan Hasil Belajar Pemahaman Konsep Dan Hasil Belajar Kognitif Siswa Kelas V Pada Pembelajaran IPA, Jurnal Pembelajaran Dan Pengajaran Pendidikan Dasar., Vol 2, No 2.

Triwahyu R, 2018, Upaya Meningkatkan Pemahaman Siswa dalam Pembelajaran Matematika Melalui Penerapan Pendekatan Konstruktivisme, Journal of Primary Education, Vol 1, Nomor 2, hal 45-53. 